\title{
Subcutaneous Emphysema During Third Molar Surgery: A Case Report
}

\author{
Umberto ROMEO \\ Alexandros GALANAKIS \\ Francesco LERARIO \\ Gabriele Maria DANIELE \\ Gianluca TENORE \\ Gaspare PALAIA
}

Department of Oral Sciences, Sapienza, University of Rome, Rome, Italy

\begin{abstract}
Extraction of third molars is the most common surgical procedure performed in oral surgery on a daily basis and, despite surgical skills and expertise, complications may occur. Complications observed during or after third molar removal may include pain, swelling, bleeding, infection, sinus perforation and nerve damage. Fortunately, with a proper management and a good surgical technique, the incidence of such events is low. Subcutaneous emphysema associated with dental extraction occurs when the air from the high-speed dental handpiece is forced into the soft tissue through the reflected flap and invades the adjacent tissues, leading to swelling, crepitus on palpation and occasionally spreading through the tissue spaces of the fascial planes. Although rare, iatrogenic subcutaneous emphysema can have serious and potentially life-threatening consequences. Care should be taken when using air-driven handpieces. The access of air into the facial tissues is not limited to tooth extractions, but may also occur through other portals of entrance, such as endodontically treated teeth, periodontium and lacerations of intraoral soft tissues. When subcutaneous emphysema occurs, it must be quickly diagnosed and properly managed to reduce the risk of further complications. This report presents a case of subcutaneous emphysema occurred during extraction of a mandibular third molar extraction with the use of an air turbine handpiece. Case management is described and issues relative to the diagnosis and prevention of this surgical complication are discussed.
\end{abstract}

Key Words: subcutaneous emphysema, third molar extraction, high pressure air instruments.

\section{INTRODUCTION}

The surgical extraction of third molars is, on a daily basis, the most frequent surgical procedure performed in oral surgery (1). Despite surgical skills and expertise, complications may occur (2).

Subcutaneous emphysema is an uncommon clinical complication of dental treatment caused by forceful injection of air into the loose connective tissue below the dermal layer. High-speed air turbine drills are used to section the tooth to facilitate extraction, and are driven by compressed air at $3.5-4.0 \mathrm{kgf} / \mathrm{cm}^{2}$, rotating at $450,000 \mathrm{rpm}$ (3). Once under the dermal layer, the air may remain locally at the surgical site or continue to spread along the loose connective tissue plane. The clinical results are local swelling, tenting of the skin and crepitation on palpation (4). In extreme cases, air could pass through the masticatory space into the parapharyngeal and retropharyngeal areas, penetrating into the mediastinum (3).

The following report presents a case of subcutaneous emphysema occurred during third molar extraction with the use of an air turbine handpiece. Case management is described and issues relative to the diagnosis and prevention of this surgical complication are discussed.

\section{CASE REPORT}

A 25-year-old female patient was referred to the Department of Oral Sciences of the University of Rome by her private dentist for extraction of the mandibular right third molar, which was impacted in the mandible, in horizontal position, with fused roots and 
near the mandibular canal (Fig. 1). Oral and physical examinations, including radiography and computed tomography (CT) scanning, were performed. Medical history was not relevant for systemic conditions and the routine preoperative laboratory tests, including coagulation screening tests, were within normal ranges. Based on these findings, surgery was scheduled under local anesthesia.

Using a Bard Parker \#15 scalpel blade, a triangular surgical flap with was made with a release incision mesially to the second molar and adjacent to the papilla. The mucoperiosteal flap was raised, exposing the overlying bone and maintained with a Langenbeck retractor. In order to expose the tooth crown, ostectomy was performed using a Lindemann stainless steel bur on a low-speed straight handpiece with copious sterile saline irrigation. Then, an air-driven high-speed turbine was used for tooth sectioning.

During this surgical phase, the air turbine handpiece was inclined towards the bucal face of the tooth to avoid damage to the lingual nerve. The handpiece was therefore "immersed" within the flap that was non correctly held in place by the assistant surgeon. The air produced by the turbine followed the free way constituted by the partially disinserted fibers of the masseter muscle. Almost immediately after tooth sectioning, the right side of the patient's face became swollen from the inferior border of the mandible to the attachment of the temporalis muscle. The swelling immediately closed the patient's right eye. The patient did not have pain, tenderness to palpation, or difficulty breathing as a result of the swelling. However, she did note a fullness sensation of her face and she could not open his right eye (Fig. 2).

The subcutaneous emphysema was located in the latero-cervical, cheek and orbital region, causing the immediate closure of the eyelids. The surgical

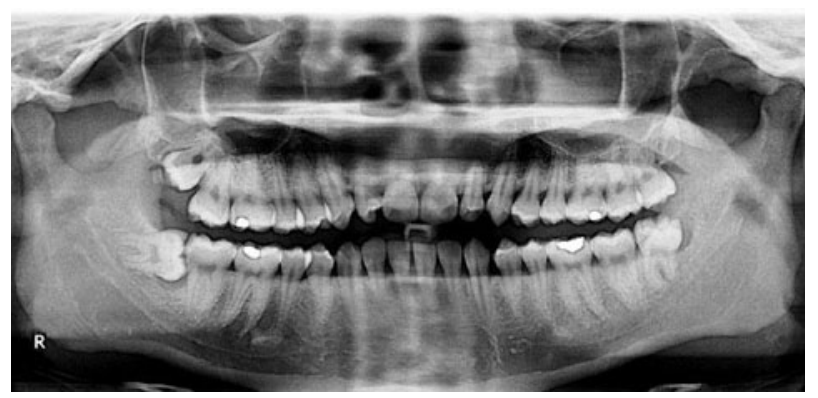

Figure 1. Preoperative radiograph showing the impacted mandibular right third molar. intervention was immediately suspended and $8 \mathrm{mg}$ of betamethasone (Bentelan; Defiante Farm Unipessoal LDA, Funchal, Portugal) together with $1.5 \mathrm{~g}$ of ampicillin/sulbactam (Unasyn; Pfizer Italia, Latina, Italy) were immediately administered endovenously. Reductive manipulation was also performed.

Surgical procedure was carried out using a contra angle multiplier (1:5) handpiece. After tooth removal, abundant saline irrigation was performed and the flap was sutured using a $3 / 0$ silk sutures. The patient was kept under observation for $2 \mathrm{~h}$ and antibiotic (ampicillin/ sulbactam $3 \mathrm{gr} / \mathrm{die}$ for 5 days) and analgesic (ketoprofen $80 \mathrm{mg}$ every $12 \mathrm{~h}$ for 3 days) therapy was administered.

Follow-up visits were scheduled on a 2-day basis (Figs. 3 and 4). Sutures were removed after 7 days when control photographs were taken and signs of emphysema were no longer noticeable. No further local, systemic and infectious complications occurred.

\section{DISCUSSION}

Subcutaneous emphysema in oral surgery is caused by entry of air into the fascial spaces of the face and neck, resulting in distention of the overlying skin or mucosa.

In order to perform a correct treatment, it is important to make differential diagnosis with complications that also produce swelling of the soft tissues, such as hematoma, allergic reaction or

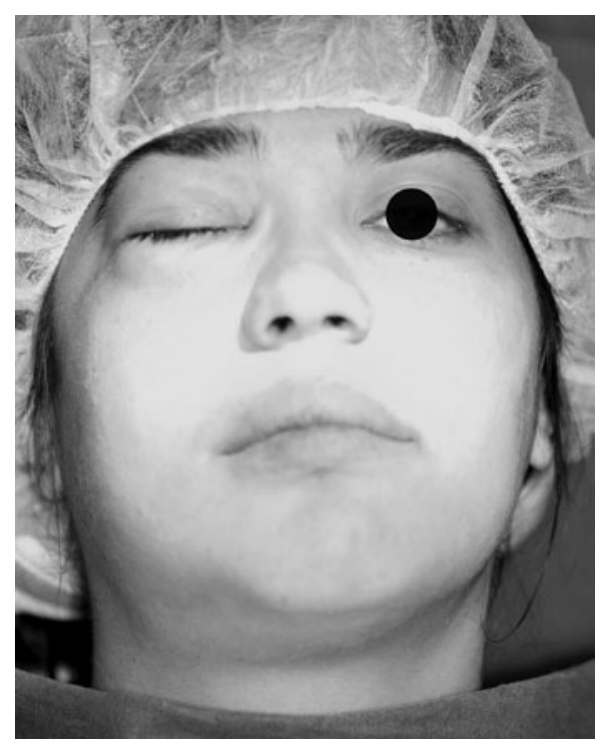

Figure 2. Clinical features of subcutaneous emphysema immediately after its occurrence. 
angioedema (5). Palpation of the swollen head and neck areas will elicit crepitus, or a "Velcro" sensation, that is not present in the other conditions (6). In most cases, this sign is detected immediately, but there are reports in which it may appear subsequently, making diagnosis difficult (7).

Subcutaneous emphysema is an uncommon complication in dental routine. McKenzie and Rosenberg (4), in a recent literature review, examined 32 cases of subcutaneous emphysema. Half of the cases were associated with the use of air-driven handpieces. Five of the cases reviewed resulted in significant complications after subcutaneous emphysema.

It should be noticed that surgery is not the only procedure at risk for the development of subcutaneous emphysema, as cases have been described during restorative procedures, crown preparation, and endodontic therapy (4). Emphysema has also been reported during oral laser surgery procedures (8). Air can be introduced into the soft tissue spaces by several routes, but it usually passes through the dentoalveolar membrane or a root canal (9).

Elevation of a large flap can raise the risk of provoking emphysema, especially during third molar surgery. Air can diffuse into the pterygomaxillary region and into the lateral pharyngeal space from the molar-retromolar region, and reach the mediastinum by dissecting the visceral space. Air can penetrate the cervical fascial planes and extend to the mediastinum,

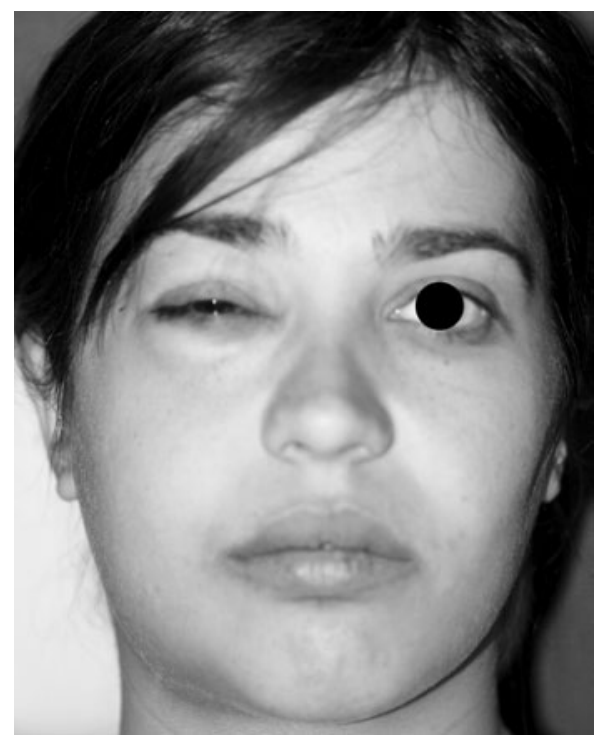

Figure 3. Control photograph at 2 days, showing partial regression of facial swelling. leading to more life threatening consequences (10). The presence of pain both in the thorax and in the back, would suggest the presence of mediastinic emphysema, and a chest film to confirm the diagnosis is mandatory (7).

Although infection is not usually observed in a subcutaneous emphysema, cases have been described where this condition has developed. Prophylactic antibiotic therapy is recommended, since the introduction of air and non-sterile water could cause serious effects to the patient's health (7).

Most cases of subcutaneous emphysema start resolving after 3 to 5 days, and they are completely managed after 7 to 10 days (4). It is important to advise patients to avoid increasing the intraoral pressure by blowing the nose vigorously or playing musical instruments, for example, as these procedures could cause introduction of more air (11).

In the present case, the air could have been forced into subcutaneous tissues during tooth sectioning with the high-speed air turbine handpiece and the elevated flap could have provoked a valve effect as described in other clinical situations $(12,13)$.

Prevention of emphysema requires adherence to well-accepted surgical procedures. Mucoperiosteal flap elevation should be minimal and should not extend to the lingual alveolus of the mandibular third molar area. Muscle attachments should be preserved whenever possible. Firm but gentle retraction of mucoperiosteal flaps protects soft tissues from cutting instruments.

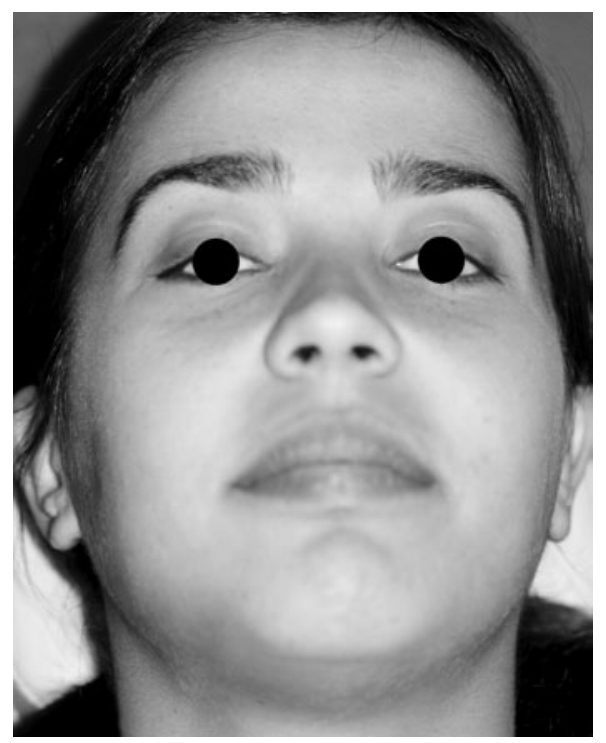

Figure 4. Control photograph at 4 days showing an almost complete recovery. 
Moreover, air turbine high-speed handpieces should not be used for longer than required (10). It is preferable to use a contra-angle multiplier (1:5) handpiece, which does not use a flux of high speed air for movement. In every case, prompt diagnosis is important to avoid lifethreatening consequences such as pneumomediastinum or pneumothorax.

\section{RESUMO}

A extração de terceiros molares é o procedimento cirúrgico mais comum na prática diária em cirurgia oral, e complicações podem ocorrer a despeito da habilidade e experiência do cirurgião. Complicações observadas durante ou após extração de terceiros molares podem incluir dor, edema, sangramento, infecção, perfuração de seio e dano nervoso. Felizmente, a incidência de tais eventos é baixa quando se emprega conduta adequada e boa técnica cirúrgica. $\mathrm{O}$ enfisema subcutâneo associado à extração dentária ocorre quando o ar da turbina de alta rotação é forçado para dentro dos tecidos moles através de um retalho rebatido e invade os tecidos adjacentes, causando edema, crepitação à palpação, e eventualmente espalhando-se pelos espaços teciduais dos planos fasciais. Embora seja raro, o enfisema subcutâneo iatrogênico pode ter conseqüências sérias e com risco de morte. É necessário ter cuidado com o uso de turbinas de alta rotação durante a realização de procedimentos cirúrgicos orais. A penetração de ar nos tecidos faciais não está limitada às extrações dentárias, e pode ocorrer também por outras vias de acesso, tais como dentes tratados endodonticamente, periodonto e lacerações de tecidos moles intraorais. Quando ocorre, o enfisema subcutâneo deve ser diagnosticado rapidamente e tratado adequadamente para diminuir o risco de outras complicações. Este relato apresenta um caso de enfisema subcutâneo ocorrido durante a extração de um terceiro molar inferior com emprego de turbina de alta rotação. O manejo do caso é descrito e os aspectos relacionados ao diagnóstico e à prevenção desta complicação cirúrgica são discutidos.

\section{REFERENCES}

1. Kunkel M, Morbach T, Kleis W, Wagner W. Third molar complications requiring hospitalization. Oral Surg Oral Med Oral Pathol Oral Radiol Endod 2006;102:300-306.

2. Jerjes W, Upile T, Nhembe F, Gudka D, Shah P, Abbas S, et al.. Experience in third molar surgery: an update. Br Dent $\mathrm{J}$ 2010;209:E1.

3. Arai I, Aoki T, Yamazaki H, Ota Y, Kaneko A. Pneumomediastinum and subcutaneous emphysema after dental extraction detected incidentally by regular medical checkup: a case report. Oral Surg Oral Med Oral Pathol Oral Radiol Endod 2009;107:e33-e38.

4. McKenzie WS, Rosenberg M. Iatrogenic subcutaneous emphysema of dental and surgical origin: a literature review. J Oral Maxillofac Surg 2009;67:1265-1268.

5. Bohnenkamp DM. Subcutaneous facial emphysema resulting from routine tooth preparation: a clinical report. J Prosthet Dent 1996;76:1-3.

6. Salib RJ, Valentine DLO, Atchtar S. Surgical emphysema following dental treatment. J Laryngol Otol 1999;133:756-758.

7. Gamboa Vidal CA, Vega Pizarro CA, Almeida Arriagada A. Subcutaneous emphysema secondary to dental treatment: case report. Med Oral Patol Oral Cir Bucal 2007;12:76-78.

8. Imai T, Michizawa M, Arimoto E, Kimoto M, Yura Y. Cervicofacial subcutaneous emphysema and pneumomediastinum after intraoral laser irradiation. J Oral Maxillofac Surg 2009;67:428-430.

9. Kim Y, Kim MR, Kim SJ. Iatrogenic pneumomediastinum with extensive subcutaneous emphysema after endodontic treatment: report of 2 cases. Oral Surg Oral Med Oral Pathol Oral Radiol Endod 2010;109:e114-e119.

10. Sekine J, Irie A, Dotsu H, Inokuchi T. Bilateral pneumothorax with extensive subcutaneous emphysema manifested during third molar surgery. A case report. Int J Oral Maxillofac Surg 2000;29:355357.

11. Ali A, Cunliffe DR, Watt-Smith SR. Surgical emphysema and pneumomediastinum complicating dental extraction. Br Dent $\mathrm{J}$ 2000;188:589-590

12. Smatt Y, Browaeys H, Genay A, Raoul G, Ferri J. Iatrogenic pneumomediastinum and facial emphysema after endodontic treatment. Br J Oral Maxillofac Surg 2004;42:160-162.

13. Kung JC, Chuang FH, Hsu KJ, Shih YL, Chen CM, Huang IY. Extensive subcutaneous emphysema after extraction of a mandibular third molar: a case report. Kaohsiung J Med Sci 2009;25:562-566. 